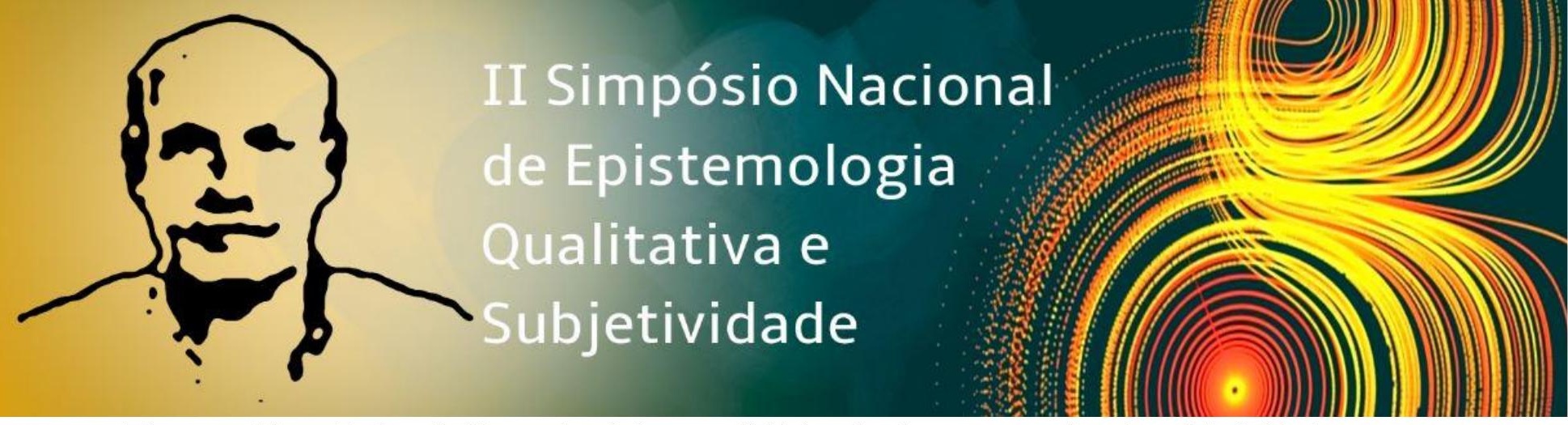

Eixo temático: 7. O trabalho pedagógico e a didática desde a perspectiva da subjetividade

\title{
O trabalho pedagógico e o Sistema Didático Integral: \\ Por um novo posicionamento docente
}

Virgínia Silva, Secretaria de Educação do Distrito Federal, silva.virginia.prof.4@gmail.com Roseane P. da Cunha, Secretaria de Educação do Distrito Federal, roseane.p.cunha@bol.com.br

\section{Resumo}

Estratégias de ensino escolar integram o cotidiano da sala de aula em que os professores planejam conforme suas concepções de ensino e de aprendizagem. Algumas práticas emergem de uma orientação empirista e descritiva da aprendizagem, baseando-se predominantemente na utilização de estratégias isoladas, distantes da complexidade que constitui a escola. Tais estratégias partem de objetivos e metodologias específicas para produzir resultados préestabelecidos na aprendizagem dos estudantes e definem uma forma fragmentada de organização didática que pode reforçar uma relação de causa e efeito entre trabalho docente e aprendizagem discente. Contudo, existem, na contemporaneidade, proposições que visam superar esse modelo. São formas de compreender a organização da sala de aula como um sistema complexo constituído pelos e nos diferentes contextos relacionais dos partícipes do processo escolar. Com base nos pressupostos sobre a constituição subjetiva dos indivíduos e dos espaços sociais, desenvolvidos pela Teoria da Subjetividade - TS (REY e MARTÍNEZ, 2017), o objetivo do trabalho é discutir a atuação docente a partir da análise da congruência da TS com o Sistema Didático Integral - SDI (MITJÁNS MARTÍNEZ, 1997, 2012) na organização didática da sala de aula. A proposta surge desde a prática de uma professora no $3^{\circ}$ ano do Ensino Fundamental de uma escola pública de Brasília. Essa docente baseia-se em formas de ação que, com base nos referenciais, podem qualificar o processo dialógico entre ensino e aprendizagem e na percepção dos desafios de uma prática docente que toma a TS e o SDI como referenciais no contexto escolar. O SDI foi proposto nos estudos do desenvolvimento da aprendizagem criativa (MITJÁNS MARTÍNEZ, 1997, 2012) e é uma concepção que busca superar a uniformidade na constituição das atividades desenvolvidas em sala de aula e pode 


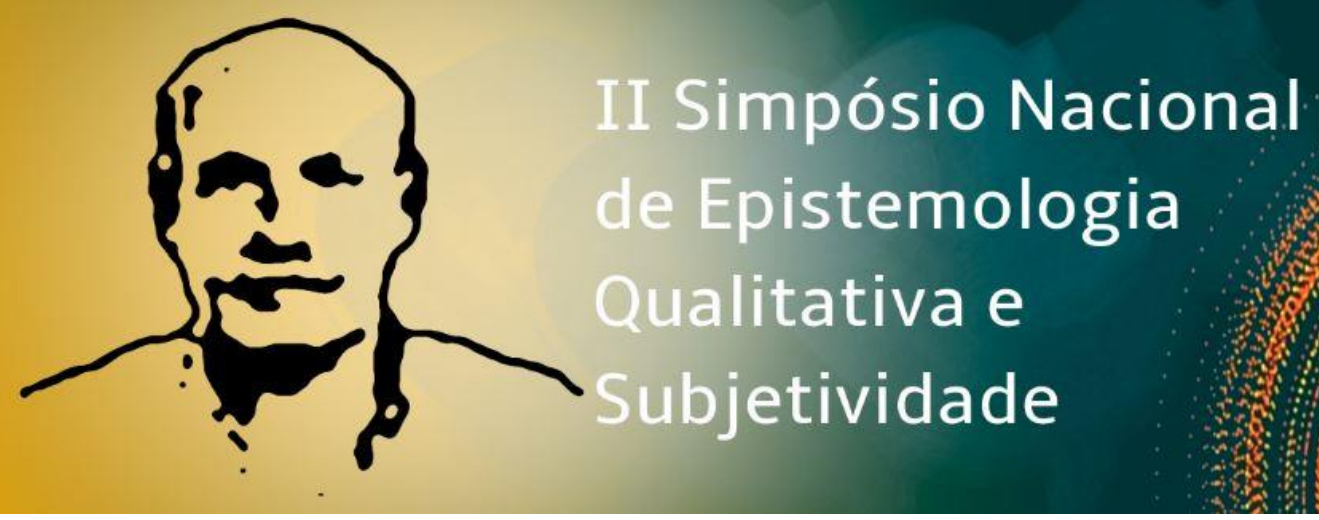

favorecer espaços de aprendizagem como uma produção subjetiva (GONZÁLEZ REY, 2009). Segundo a autora, o SDI organiza-se a partir da análise dos objetivos, dos conteúdos, do caráter produtivo necessário à ação de ensino, das maneiras como o docente organiza seu processo de trabalho, da forma produtiva como as tarefas escolares e extraescolares são propostas, da qualidade da bibliografia utilizada por docentes e estudantes, da organização do material didático disposto para ou produzido pela turma - utilizados a partir de orientação problematizadora de leitura e o meio pelo qual a avaliação e a autoavaliação são realizadas, tendo como base contextual o ambiente tensionador que possibilite a criação e não reprodução de conteúdos/ações/respostas. Possibilita romper com organizações didáticas que visam somente ao acúmulo e reprodução dos conteúdos curriculares compulsórios e superar atuações docentes que uniformizam e perpetuam ações de ensino que, por vezes, não contribuem para uma aprendizagem como produção subjetiva. Levanta-se a questão sobre o valor heurístico da proposta do SDI e de sua consequente consideração na organização didática da sala de aula desde a perspectiva de constituição subjetiva do contexto escolar. Acredita-se que a discussão possa favorecer o desenvolvimento de novos posicionamentos docentes e a emergência de novas formas de organização didática ao se relacionar com os processos de ensino e de aprendizagem em sua complexidade.

Palavras chave: Trabalho pedagógico, Subjetividade, Sistema Didático Integral

\section{Referências}

GONZÁLEZ REY, F. L. Questões Teóricas e Metodológicas nas Pesquisas sobre a Aprendizagem. In: MITJÁNS MARTÍNEZ, A.; TACCA, M. C. V. R. A Complexidade da Aprendizagem: Destaque ao Ensino Superior. Campinas, SP: Alínea, 2009. Cap. 5, p. 119-147.

MARTÍNEZ MITJÁNS, A.; GONZÁLEZ REY, F. L. O subjetivo e o Operacional na Aprendizagem Escolar: pesquisas e reflexões. In: MARTÍNEZ MITJÁNS, A.; SCOZ, B. J. L.; CASTANHO, M. I. S. (. Ensino e Aprendizagem: a subjetividade em foco. Brasília: Liber Livros, 2012. Cap. 3, p. 59-83.

MITJÁNS MARTíNEZ, A. Criatividade, personalidade e educação. Campinas - SP: Papirus, 1997.

MITJÁNS MARTÍNEZ, A. Aprendizagem Criativa: desafios para a prática pedagógica. In: NUNES, C. P. Didática e Formação de Professores. Ijuí: Unijuí, 2012. Cap. 5, p. 93-124. 